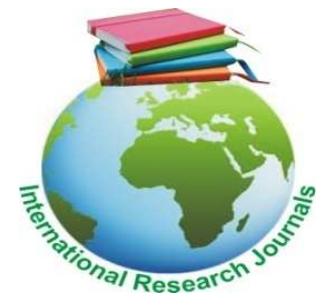

International Research Journal of Agricultural Science and Soil Science (ISSN: 2251-0044) Vol. 7(2) pp. 018-025, April, 2017

Available online http://www.interesjournals.org/IRJAS

DOI: http:/dx.doi.org/10.14303/irjas.2016.031

Copyright (C) 2017 International Research Journals

Full Length Research Paper

\title{
Selected soil chemical properties as affected by cropping system, nitrogen fertilizer and locations
}

\author{
Sebetha E.T ${ }^{1}$, Modi A.T ${ }^{2}$, Owoeye L.G ${ }^{3}$ \\ ${ }^{1}$ Crop Science Department, Faculty of Agriculture, Science and Technology, Northwest, University, Mafikeng Campus, \\ Private Bag x 2046, Mmabatho 2735. \\ ${ }^{2}$ Crop Science, School of Agriculture, Earth and Environmental Sciences, University of KwaZulu-Natal, Private Bag x 01 , \\ Scottsville 3209 \\ ${ }^{3}$ ARC-IIC, Private Bag x 82075, Rustenburg 0300 \\ ${ }^{*}$ Corresponding Author's E-mail: Erick.Sebetha@nwu.ac.za
}

\begin{abstract}
The type of cropping system that increase the soil chemical properties is very complex and the correlation between soil chemical properties on maize need to be addressed. In this way, the study was conducted to investigate the effect of cropping system, location and nitrogen fertilizer on soil chemical properties. A factorial experiment randomized in complete block design with two replications was conducted during 2011/12 and 2012/13 planting seasons. The experiment consisted of five management systems, namely, mono cropping cowpea, Mono cropping maize, rotational maize, rotational cowpea and intercropping maize-cowpea. The amount of 0 and $95 ; 0$ and $92 ; 0$ and $113.5 \mathrm{~kg} \mathrm{~N} \mathrm{ha}^{-1}$ were applied on maize plots, while the amount of 0 and 20; 0 and 17; 0 and $23.5 \mathrm{~kg} \mathrm{~N} \mathrm{ha}^{-1}$ were applied on cowpea plots at Potchefstroom, Rustenburg and Taung respectively. The laboratory analysis involved soil N$\mathrm{NO}_{3}, \mathrm{~N}-\mathrm{NH}_{4}$, Bray 1-P and exchangeable $\mathrm{K}$. Soil collected from cowpea plots planted on mono cropping and rotational systems had significantly $(\mathrm{P}<0.05)$ higher soil $\mathrm{N}-\mathrm{NO}_{3}$ than soil collected at other cropping systems. Soil collected at maize plot planted on mono cropping and intercropping systems had significantly $(P<0.05)$ higher Bray $1-P$ than soil collected on other cropping systems. Location had significant $(\mathrm{P}<0.05)$ effect on Bray $1-\mathrm{P}, \mathrm{N}-\mathrm{NO}_{3}$ and exchangeable $\mathrm{K}$. It was revealed that cropping system and location play a pivotal role on soil chemical properties.
\end{abstract}

Keywords: Soil N-NO ${ }_{3}$, Soil N-NH${ }_{4}$, Bray 1-P, Exchangeable K.

\section{INTRODUCTION}

The conservational cropping systems such as rotation and intercropping are known to improve soil structure and fertility. Cropping system has an immense effect on physical and chemical soil properties and also on crop productivity (Alam et al., 2014). Soil and crop management decisions affect soil quality, soil nutrient dynamics and soil chemical properties (Tittonell et al., 2008). They further indicated that those management decisions include crop rotation, residue management and the intensity and frequency of tillage. Unsuitable management practices cause degradation in soil health as well as decline in crop productivity (Alam et al., 2014).
Based on the findings of previous studies, there was significant effect of cropping system on nitrogen, potassium and phosphorus content of soil (Dahmardeh et al., 2010). It was further indicated that the lowest of N, P and $\mathrm{K}$ was obtained at sole maize. Nitrogen, phosphorus and potassium content following sole maize was significantly less than that following sole cowpea and intercrops. Biological nitrogen fixation plays an important role in the nitrogen uptake of cereal-legume intercropping (Sanginga and Woomer, 2009).

Intercrop maize with a legume are able to reduce the amount of nutrients taken from the soil as compared to a 
maize mono crop (Seran and Brintha, 2010). During absence of nitrogen fertilizer, intercropped legumes will fix nitrogen from the atmosphere and not compete with maize for nitrogen resources (Adu-Gyamfi et al., 2007).

The inclusion of legumes in rotations increased soil total $\mathrm{N}$ and mineral $\mathrm{N}$ at planting of maize, as well as the residual total $\mathrm{N}$ and mineral $\mathrm{N}$ at harvest (Omokanye et al., 2011). It was indicated that the increase soil nitrate is likely to be derived from the mineralization of legume residues, because of available high quality organic matter. The legumes in rotation, because of their deep roots, can increase the $\mathrm{K}$ level through relocation of the ion to the soil surface from deeper in the soil profile (Sarker et al. 2011). Nitrogen fertilizer had a greater influence on soil properties than crop sequence (Jagadamma et al., 2007).

In this study, soil chemical composition were evaluated under different locations of different soil and climate types, and also under different cropping systems of maize and cowpea in relation to nitrogen fertilization. The rates of chemical composition were compared based on different depth of soil under different seasons. The interaction of location, cropping system, nitrogen fertilizer, soil depth and season on soil chemical composition was the main focus of this study. The main objective of this study was to determine the soil chemical composition amongst different locations and cropping systems.

\section{MATERIALS AND METHODS}

\section{Experimental sites}

The study was conducted at three different dry land localities. The department of agriculture experimental station in Taung situated at $27^{\circ} 30^{\prime} \mathrm{S}$ and $24^{\circ} 30^{\prime} \mathrm{E}$ and Agriculture Research Council-Grain Crops Institute (ARC$\mathrm{GCl}$ ) experimental station in Potchefstroom situated at $27^{\circ} 26^{\prime} \mathrm{S}$ and $27^{\circ} 26^{\prime} \mathrm{E}$. The Agricultural Research Council-Institute for Industrial Crops (ARC-IIC) experimental station in Rustenburg is situated at $25^{\circ} 43^{\prime} \mathrm{S}$ and $27^{\circ} 18^{\prime} \mathrm{E}$. The ARC-GCl experimental station has clay percentage of 34 and receives mean rainfall of 622.2 $\mathrm{mm}$, with daily temperature range of 9.1 to $25.2^{\circ} \mathrm{C}$ d uring planting (Macvicar et al. 1977). The ARC-IIC experimental station has clay percentage of 49.5 and receives an average mean rainfall of $661 \mathrm{~mm}$. Taung experimental site is situated in grassland savannah with mean rainfall of $1061 \mathrm{~mm}$ that begins in October. Potchefstroom (ARC-GCl) has plinthic catena soil, eutrophic, red soil widespread (Pule-Meulenberg et al. 2010). The soil at Taung is described as Hutton, deep, fine sandy dominated red freely drained, eutrophic with parent material that originated from Aeolian deposits (staff, 1999).
The soil at Rustenburg (ARC-IIC) has dark, olive grey and clay soil, bristle consistency, medium granular structure (Botha et al. 1968).

\section{Experimental design}

The experiment consisted of five cropping systems, which were mono cropping cowpea, Mono cropping maize, rotational maize, rotational cowpea and intercropping maize-cowpea. The optimum rate of $\mathrm{N}$ to be applied at Potchefstroom and Rustenburg on maize was $100 \mathrm{~kg} \mathrm{ha}^{-1}$ and on cowpea was $25 \mathrm{~kg} \mathrm{ha}^{-1}$. At Taung, the optimum amount of $\mathrm{N}$ to be applied on maize was $120 \mathrm{~kg}$ $\mathrm{ha}^{-1}$ and on cowpea was $30 \mathrm{~kg} \mathrm{ha}^{-1}$. The results of soil analysis before planting indicated the amount of $5 \mathrm{~kg} \mathrm{~N}$ $\mathrm{ha}^{-1}$ available at Potchefstroom, $8 \mathrm{~kg} \mathrm{~N} \mathrm{ha}^{-1}$ available at Rustenburg and $6.5 \mathrm{~kg} \mathrm{~N} \mathrm{ha}^{-1}$ was available at Taung. The amount of 0 and $95 \mathrm{~kg} \mathrm{~N}^{-1}$ were applied on the plots of maize at Potchefstroom, 0 and $92 \mathrm{~kg} \mathrm{~N} \mathrm{ha}^{-1}$ were applied at Rustenburg and 0 and $113.5 \mathrm{~kg} \mathrm{~N} \mathrm{ha}^{-1}$ were applied at Taung. The amount of 0 and $20 \mathrm{~kg} \mathrm{~N} \mathrm{ha}^{-1}$ were applied on cowpea plots at Potchefstroom, 0 and $17 \mathrm{~kg} \mathrm{~N}$ $\mathrm{ha}^{-1}$ were applied on cowpea plots at Rustenburg and 0 and $23.5 \mathrm{~kg} \mathrm{~N}^{-1}$ were applied on cowpea plots at Taung. The experiment was established in 2010/11 planting season and data considered for experiment was collected during 2011/12 and 2012/13 planting seasons. The experimental design was factorial experiment laid out in random complete block design (RCBD) with two replicates. Maize cultivar (PAN 6479) and cowpea (Bechuana white) were used as test crop.

\section{Data collection, laboratory procedure and analysis}

Soil samples were collected at the depth of $0-15$ and 15$30 \mathrm{~cm}$. Soil samples collected were sent to ARC-IIC for analysis of $\mathrm{N}-\mathrm{NO}_{3}$, phosphorus (Bray 1-P) and exchangeable $\mathrm{K}$. Total nitrogen was determined according to the Kjeldah digestion procedure and $\mathrm{N}-\mathrm{NH}_{4}$ and $\mathrm{N}-\mathrm{NO}_{3}$ were determined following $\mathrm{IM} \mathrm{KCl}$ extraction. Available $\mathrm{P}$ was determined using Bray I procedure described by Bray and Kurts (1945). Exchangeable K was extracted using neutral normal ammonium acetate solution and $\mathrm{K}$ concentration in solution read on atomic absorption spectrophotometer (AAS). Analysis of variance was performed using Gen Stat $14^{\text {th }}$ edition (2012). Least significant difference (LSD) was used to separate means. A probability level of less than 0.05 was considered as significant statistically (Gomez and Gomez, 1984).The second order interactions were considered on soil $\mathrm{N}^{-\mathrm{NO}_{3}}$ and Bray 1-P. The first order interactions were considered on soil $\mathrm{N}-\mathrm{NH}_{4}$. The third order interactions were considered on soil exchangeable 
020 Int. Res. J. Agric. Sci. Soil Sci.

Table 1. The results of soil chemical properties $\left(\mathrm{mg} \mathrm{kg}^{-1}\right)$ of samples collected before planting at three sites.

\begin{tabular}{|c|c|c|c|}
\hline Site & Chemical properties & $0-15 \mathrm{~cm}$ & $15-30 \mathrm{~cm}$ \\
\hline \multirow[t]{5}{*}{ Potchefstroom } & $\mathrm{pH}(\mathrm{KCl})$ & 5.84 & 5.81 \\
\hline & $\mathrm{N}-\mathrm{NO}_{3}$ & 2.25 & 2.90 \\
\hline & $\mathrm{N}-\mathrm{NH}_{4}$ & 1.25 & 0.65 \\
\hline & P (Bray-1) & 41 & 42 \\
\hline & $\mathrm{K}$ & 348 & 318 \\
\hline \multirow[t]{5}{*}{ Taung } & $\mathrm{pH}(\mathrm{KCl})$ & 6.51 & 6.63 \\
\hline & $\mathrm{N}-\mathrm{NO}_{3}$ & 2.50 & 1.50 \\
\hline & $\mathrm{N}-\mathrm{NH}_{4}$ & 0.75 & 0.75 \\
\hline & P (Bray-1) & 7 & 7 \\
\hline & K & 108 & 118 \\
\hline \multirow[t]{5}{*}{ Rustenburg } & $\mathrm{pH}(\mathrm{KCl})$ & 4.87 & 5.07 \\
\hline & $\mathrm{N}-\mathrm{NO}_{3}$ & 3.25 & 1.40 \\
\hline & $\mathrm{N}-\mathrm{NH}_{4}$ & 0.75 & 0.50 \\
\hline & P (Bray-1) & 4 & 2 \\
\hline & K & 150 & 88 \\
\hline
\end{tabular}

Table 2. The interaction effect of cropping system $x$ nitrogen fertilizer $x$ season on soil $\mathrm{N}-\mathrm{NO}_{3}$.

\begin{tabular}{|c|c|c|c|c|}
\hline \multirow[t]{2}{*}{ Cropping system } & \multicolumn{2}{|c|}{$\mathrm{N}$-Fertilizer } & \multicolumn{2}{|c|}{ Zero-Nitrogen } \\
\hline & $2011 / 12$ & $2012 / 13$ & $2011 / 12$ & $2012 / 13$ \\
\hline Intercropping & 3.64 & 3.19 & 2.85 & 2.82 \\
\hline Monocowpea & 3.84 & 2.78 & 3.78 & 4.31 \\
\hline Monomaize & 2.22 & 2.43 & 1.70 & 1.06 \\
\hline Rotacowpea & 3.84 & 3.52 & 2.93 & 2.69 \\
\hline Rotamaize & 1.73 & 2.28 & 2.16 & 1.26 \\
\hline $\operatorname{LSD}_{(0.05)}$ & 0.90 & & & \\
\hline
\end{tabular}

Monocowpea $=$ Monocropping cowpea; Monomaize $=$ Monocropping maize; Rotacowpea $=$ Rotational cowpea; Rotamaize $=$ Rotational cowpea.

$\mathrm{K}$. The results of soil chemical properties collected before planting at three locations are indicated on Table 1.

\section{RESULTS}

\section{Soil nitrate $\left(\mathrm{N}-\mathrm{NO}_{3}\right)$ content at harvest}

The interaction of cropping system $x$ nitrogen fertilizer $x$ season $(\mathrm{P}<0.01)$ had significant effect on soil $\mathrm{N}-\mathrm{NO}_{3}$ (Table 2). Soil collected in rotational cowpea, mono cropping cowpea and intercropping systems, where nitrogen fertilizer was applied had significantly higher soil $\mathrm{N}-\mathrm{NO}_{3}$ of $3.84,3.84$ and $3.64 \mathrm{mg} / \mathrm{kg}$ respectively than other cropping systems during 2011/12 planting season. During 2012/13 planting season, soil collected under nitrogen fertilizer plots in rotational cowpea and intercropping systems had significantly higher $\mathrm{N}-\mathrm{NO}_{3}$ of
3.52 and $3.19 \mathrm{mg} / \mathrm{kg}$ respectively than other cropping systems. During 2011/12 planting season, soil collected under zero-nitrogen fertilizer plots in rotational cowpea, intercropping and mono cropping cowpea systems had significantly higher $\mathrm{N}^{-\mathrm{NO}_{3}}$ of $2.93,2.85$ and $3.78 \mathrm{mg} / \mathrm{kg}$ respectively than other cropping systems. During 2012/13 planting season, soil collected under zero nitrogen fertilizer plots in mono cropping cowpea, intercropping and rotational cowpea systems had significantly higher $\mathrm{N}$ $\mathrm{NO}_{3}$ of $4.31,2.82$ and $2.69 \mathrm{mg} / \mathrm{kg}$ respectively than other cropping systems.

The interaction of location $\mathrm{x}$ nitrogen fertilizer $\mathrm{x}$ season $(\mathrm{P}<0.004)$ had significant effect on soil $\mathrm{N}-\mathrm{NO}_{3}$ (Table 3 ). Soil collected under nitrogen fertilizer plots at Potchefstroom and Taung had significantly higher $\mathrm{N}-\mathrm{NO}_{3}$ of 4.64 and $2.84 \mathrm{mg} / \mathrm{kg}$ respectively during 2011/12 planting season. During 2012/13 planting season, soil collected under nitrogen fertilizer plots at Rustenburg and 
Table 3. The interaction effect of location $x$ nitrogen fertilizer $x$ season on soil $\mathrm{N}-\mathrm{NO}_{3}$ in $\mathrm{mg} / \mathrm{kg}$.

\begin{tabular}{lcccc}
\hline Location & \multicolumn{2}{c}{ N-Fertilizer } & \multicolumn{2}{c}{ Zero-Nitrogen } \\
\hline & $2011 / 12$ & $2012 / 13$ & $2011 / 12$ & $2012 / 13$ \\
\cline { 2 - 5 } Potchefstroom & 4.64 & 2.00 & 4.33 & 1.43 \\
Rustenburg & 1.68 & 3.69 & 1.52 & 2.42 \\
Taung & 2.84 & 2.83 & 2.21 & 3.44 \\
LSD $_{(0.05)}$ & 0.70 & & & \\
\hline
\end{tabular}

Table 4. The interaction effect of location $x$ soil depth $x$ season on soil $\mathrm{N}-\mathrm{NO}_{3}$ in $\mathrm{mg} / \mathrm{kg}$.

\begin{tabular}{lcccc}
\hline Location & \multicolumn{2}{c}{$\mathbf{0 - 1 5} \mathbf{~ c m}$} & \multicolumn{2}{c}{$\mathbf{1 5 - 3 0} \mathbf{~ c m}$} \\
& $2011 / 12$ & $2012 / 13$ & $2011 / 12$ & $2012 / 13$ \\
Potchefstroom & 6.03 & 2.10 & 2.93 & 1.32 \\
Rustenburg & 2.01 & 3.61 & 1.19 & 2.50 \\
Taung & 3.32 & 4.22 & 1.73 & 2.04 \\
LSD $_{(0.05)}$ & 0.70 & & & \\
\hline
\end{tabular}

Table 5. The interaction effect of location $x$ soil depth on soil $\mathrm{N}-\mathrm{NH}_{4}$ in $\mathrm{mg} / \mathrm{kg}$

\begin{tabular}{lcc}
\hline Location & $\mathbf{0 - 1 5} \mathbf{~ c m}$ & $\mathbf{1 5 - 3 0 ~} \mathbf{~ m}$ \\
Potchefstroom & 1.09 & 0.79 \\
Rustenburg & 0.67 & 0.53 \\
Taung & 0.37 & 0.38 \\
LSD $_{(0.05)}$ & 0.13 & \\
\hline
\end{tabular}

Taung had significantly higher $\mathrm{N}-\mathrm{NO}_{3}$ of 3.69 and 2.83 $\mathrm{mg} / \mathrm{kg}$ respectively than other location. Soil collected under zero nitrogen plots at Potchefstroom and Taung had significantly higher $\mathrm{N}-\mathrm{NO}_{3}$ of 4.33 and $2.21 \mathrm{mg} / \mathrm{kg}$ respectively than other location during 2011/12 planting season. During 2012/13 planting season, soil collected under zero nitrogen fertilizer plots at Rustenburg and Taung had significantly higher $\mathrm{N}-\mathrm{NO}_{3}$ of 2.42 and 3.44 $\mathrm{mg} / \mathrm{kg}$ respectively than other location.

The interaction of location $x$ soil depth $x$ season $(P<$ 0.001 ) had significant effect on soil $\mathrm{N}-\mathrm{NO}_{3}$ (Table 4). Soil collected at the depth of $0-15 \mathrm{~cm}$ in Potchefstroom and Taung had significantly higher $\mathrm{N}-\mathrm{NO}_{3}$ of 6.03 and 3.32 $\mathrm{mg} / \mathrm{kg}$ respectively. During 2012/13 planting season, soil collected at the depth of $0-15 \mathrm{~cm}$ in Rustenburg and Taung had significantly higher $\mathrm{N}-\mathrm{NO}_{3}$ of 3.61 and 4.22 $\mathrm{mg} / \mathrm{kg}$ respectively. Soil collected at the depth of $15-30$ $\mathrm{cm}$ in Potchefstroom had significantly higher $\mathrm{N}-\mathrm{NO}_{3}$ of $2.93 \mathrm{mg} / \mathrm{kg}$. During 2012/13 planting season, soil collected at the depth of $15-30 \mathrm{~cm}$ in Rustenburg and Taung had significantly higher $\mathrm{N}-\mathrm{NO}_{3}$ of 2.50 and 2.04 $\mathrm{mg} / \mathrm{kg}$ respectively.

\section{Soil ammonium $\left(\mathrm{N}-\mathrm{NH}_{4}\right)$ content at harvest}

The interaction of location $x$ soil depth $(P=0.004)$ had significant effect on soil $\mathrm{N}-\mathrm{NH}_{4}$ (Table 5). Soil collected at the depth of $0-15 \mathrm{~cm}$ in Potchefstroom and Rustenburg had significantly higher soil $\mathrm{N}^{-\mathrm{NH}_{4}}$ of 1.09 and 0.67 $\mathrm{mg} / \mathrm{kg}$ respectively than other location. Soil collected in Potchefstroom and Rustenburg at the depth of $15-30 \mathrm{~cm}$ had significantly higher soil $\mathrm{N}-\mathrm{NH}_{4}$ of 0.79 and 0.53 $\mathrm{mg} / \mathrm{kg}$ respectively.

The interaction of location $x$ season $(P<0.001)$ had significant effect on soil $\mathrm{N}-\mathrm{NH}_{4}$ (Table 6). During 2011/12 planting season, soil collected at Potchefstroom and Rustenburg had significantly higher $\mathrm{N}-\mathrm{NH}_{4}$ of 1.11 and $0.75 \mathrm{mg} / \mathrm{kg}$ respectively than other location. During 2012/13 planting season, soil collected at Potchefstroom had significantly higher soil $\mathrm{N}-\mathrm{NH}_{4}$ of $0.77 \mathrm{mg} / \mathrm{kg}$ than other locations.

\section{Soil Bray 1-P content at harvest}

The interaction of cropping system $x$ location $x$ season $(P$ $=0.01$ ) had significant effect on soil Bray 1-P (Table 7). Soil collected in intercropping system at Potchefstroom during 2012/13 planting season, had significantly higher Bray $1-\mathrm{P}$ of $23.50 \mathrm{mg} / \mathrm{kg}$ than soil in mono cropping cowpea system. During 2011/12 planting season at Taung, soil collected in intercropping system had 
022 Int. Res. J. Agric. Sci. Soil Sci.

Table 6. The interaction effect of location $\mathrm{x}$ season on soil $\mathrm{N}-\mathrm{NH}_{4}$ in $\mathrm{mg} / \mathrm{kg}$

\begin{tabular}{lcc}
\hline Location & $\mathbf{2 0 1 1 / 1 2}$ & $\mathbf{2 0 1 2 / 1 3}$ \\
\hline Potchefstroom & 1.11 & 0.77 \\
Rustenburg & 0.75 & 0.45 \\
Taung & 0.32 & 0.43 \\
LSD $_{(0.05)}$ & 0.13 & \\
\hline
\end{tabular}

Table 7. The interaction effect of cropping system $x$ location $x$ season on soil Bray $1-\mathrm{P}$ in $\mathrm{mg} / \mathrm{kg}$

\begin{tabular}{lcccccc}
\hline Cropping system & \multicolumn{2}{c}{ Potchefstroom } & \multicolumn{2}{c}{ Rustenburg } & \multicolumn{2}{c}{ Taung } \\
\hline & $\mathbf{2 0 1 1 / 1 2}$ & $\mathbf{2 0 1 2 / 1 3}$ & $\mathbf{2 0 1 1 / 1 2}$ & $\mathbf{2 0 1 2 / 1 3}$ & $\mathbf{2 0 1 1 / 1 2}$ & $\mathbf{2 0 1 2} \mathbf{1 3}$ \\
\cline { 2 - 7 } Intercropping & 17.00 & 23.50 & 4.00 & 9.25 & 22.12 & 12.12 \\
Monocowpea & 13.12 & 15.25 & 3.12 & 4.00 & 9.50 & 10.87 \\
Monomaize & 17.12 & 18.12 & 4.00 & 5.62 & 13.38 & 23.12 \\
Rotacowpea & 16.12 & 19.88 & 3.75 & 4.87 & 12.62 & 14.88 \\
Rotamaize & 15.00 & 19.38 & 3.87 & 3.88 & 14.38 & 21.62 \\
LSD $(0.05)$ & 6.68 & & & & & \\
\hline
\end{tabular}

Monocowpea $=$ Monocropping cowpea; Monomaize $=$ Monocropping maize; Rotacowpea $=$ Rotational cowpea; Rotamaize = Rotational cowpea.

Table 8. The interaction effect of cropping system $\mathrm{x}$ location $\mathrm{x}$ nitrogen fertilizer $\mathrm{x}$ season on soil exchangeable $\mathrm{K}$ in $\mathrm{mg} / \mathrm{kg}$

\begin{tabular}{|c|c|c|c|c|c|}
\hline \multirow[t]{2}{*}{ Cropping system } & \multirow[t]{2}{*}{ Location } & \multicolumn{2}{|c|}{ N-Fertilizer } & \multicolumn{2}{|c|}{ Zero-Nitrogen } \\
\hline & & $2011 / 12$ & $2012 / 13$ & $2011 / 12$ & $2012 / 13$ \\
\hline \multirow[t]{3}{*}{ Intercropping } & Potch & 236.50 & 260.00 & 249.75 & 240.25 \\
\hline & Rust & 126.00 & 103.00 & 122.00 & 127.75 \\
\hline & Taung & 127.75 & 120.50 & 118.00 & 144.50 \\
\hline \multirow[t]{3}{*}{ Monocowpea } & Potch & 224.00 & 274.00 & 195.25 & 211.50 \\
\hline & Rust & 137.75 & 128.25 & 130.25 & 139.25 \\
\hline & Taung & 105.25 & 136.50 & 110.50 & 130.25 \\
\hline \multirow[t]{3}{*}{ Monomaize } & Potch & 235.25 & 227.00 & 229.00 & 242.00 \\
\hline & Rust & 144.00 & 127.75 & 132.25 & 132.75 \\
\hline & Taung & 110.25 & 115.25 & 96.50 & 117.00 \\
\hline \multirow[t]{3}{*}{ Rotacowpea } & Potch & 252.25 & 222.25 & 213.75 & 254.75 \\
\hline & Rust & 122.75 & 111.75 & 135.50 & 112.75 \\
\hline & Taung & 108.75 & 107.75 & 124.25 & 110.00 \\
\hline \multirow[t]{3}{*}{ Rotamaize } & Potch & 229.00 & 255.00 & 234.50 & 213.25 \\
\hline & Rust & 125.25 & 117.50 & 121.00 & 121.50 \\
\hline & Taung & 99.75 & 99.00 & 102.00 & 109.50 \\
\hline $\operatorname{LSD}_{(0.05)}$ & 34.18 & & & & \\
\hline
\end{tabular}

Monocowpea $=$ Monocropping cowpea; Monomaize $=$ Monocropping maize; Rotacowpea $=$ Rotational cowpea; Rotamaize = Rotational cowpea; Potch = Potchefstroom; Rust = Rustenburg.

significantly higher Bray 1-P of $22.12 \mathrm{mg} / \mathrm{kg}$ than other cropping systems. During 2012/13 planting season at Taung, soil collected in mono cropping and rotational maize systems had significantly higher Bray 1-P of 23.12 and $21.62 \mathrm{mg} / \mathrm{kg}$ respectively than other cropping systems.

\section{Soil exchangeable $\mathrm{K}$ content at harvest}

The interaction of cropping system $\mathrm{x}$ location $\mathrm{x}$ nitrogen fertilizer $x$ season $(P=0.038)$ had significant effect on exchangeable K (Table 8). In intercropping system, soil collected at Potchefstroom under nitrogen fertilizer plots 
had significantly higher exchangeable $\mathrm{K}$ of 236.50 and $260.00 \mathrm{mg} / \mathrm{kg}$ during 2011/12 and 2012/13 planting seasons respectively than other locations. Under zero nitrogen fertilizer plots, soil collected in intercropping system at Potchefstroom had significantly higher exchangeable $\mathrm{K}$ of 249.75 and $240.25 \mathrm{mg} / \mathrm{kg}$ during $2011 / 12$ and 2012/13 planting seasons respectively.

In mono cropping cowpea system, soil collected at Potchefstroom under nitrogen fertilizer plots had significantly higher exchangeable $\mathrm{K}$ of 224.00 and 274.00 $\mathrm{mg} / \mathrm{kg}$ during 2011/12 and 2012/13 planting seasons respectively than other locations. Under zero nitrogen fertilizer plots, soil collected at Potchefstroom in mono cropping cowpea system had significantly higher exchangeable $\mathrm{K}$ of 195.25 and $211.50 \mathrm{mg} / \mathrm{kg}$ during $2011 / 12$ and $2012 / 13$ planting seasons respectively.

In mono cropping maize system, soil collected at Potchefstroom under nitrogen fertilizer plots had significantly higher exchangeable $\mathrm{K}$ of 235.25 and 227.00 $\mathrm{mg} / \mathrm{kg}$ during 2011/12 and 2012/13 respectively than other locations. Under zero nitrogen fertilizer plots, soil collected at Potchefstroom had significantly higher exchangeable $\mathrm{K}$ of 229.00 and $242.00 \mathrm{mg} / \mathrm{kg}$ during $2011 / 12$ and $2012 / 13$ planting seasons respectively than other locations.

In rotational cowpea system, soil collected at Potchefstroom under nitrogen fertilizer plots had significantly higher exchangeable $\mathrm{K}$ of 252.25 and 222.25 $\mathrm{mg} / \mathrm{kg}$ during 2011/12 and 2012/13 planting seasons respectively than other locations. Under zero nitrogen fertilizer plots, soil collected at Potchefstroom had significantly higher exchangeable $\mathrm{K}$ of 213.75 and 254.75 $\mathrm{mg} / \mathrm{kg}$ during 2011/12 and 2012/13 planting seasons respectively.

In rotational maize cropping system, soil collected at Potchefstroom under nitrogen fertilizer plots had significantly higher exchangeable $\mathrm{K}$ of 229.00 and 255.00 $\mathrm{mg} / \mathrm{kg}$ during 2011/12 and 2012/13 planting seasons respectively than other locations. Under zero nitrogen fertilizer plots, soil collected at Potchefstroom had significantly higher exchangeable $\mathrm{K}$ of 234.50 and 213.25 $\mathrm{mg} / \mathrm{kg}$ during 2011/12 and 2012/13 planting seasons respectively.

\section{DISCUSSION}

\section{Soil $\mathrm{N}-\mathrm{NO}_{3}$ and $\mathrm{N}-\mathrm{NH}_{4}$}

The amount of $\mathrm{N}-\mathrm{NO}_{3}$ had increased at Potchefstroom and Taung at the end of cropping system as compared to $\mathrm{N}-\mathrm{NO}_{3}$ obtained before planting of trial (Table 1). The amount of $\mathrm{N}-\mathrm{NH}_{4}$ was decreased in soil at the end of cropping as compared to $\mathrm{N}-\mathrm{NH}_{4}$ obtained before planting at all sites. The differences of $\mathrm{N}-\mathrm{NO}_{3}$ and $\mathrm{N}-\mathrm{NH}_{4}$ across sites and seasons may have been attributed to different soil types, temperatures and rainfall. This confirmed statements by Qi et al. (2011) that there was the interactive effect of temperature and moisture on mineralization of soil nitrogen. Soil collected at Potchefstroom had higher $\mathrm{N}-\mathrm{NO}_{3}$ and $\mathrm{N}-\mathrm{NH}_{4}$, and this may have been attributed to high organic matter and soil texture of that soil, which reduced loss of nitrogen through leaching. This agreed with similar findings by Najmadeen et al. (2010) who reported the interactions among soil organic matter and total nitrogen contents with soil texture.

The amount of soil nitrate $\left(\mathrm{N}-\mathrm{NO}_{3}\right)$ should be between the critical levels of $8-12 \mathrm{mg} \mathrm{kg}^{-1}$ (Miao et al., 2015). At both $0-15$ and $15-30 \mathrm{~cm}$ depths, $\mathrm{N}-\mathrm{NO}_{3}$ was below the critical level. The higher level of $\mathrm{N}-\mathrm{NO}_{3}$ in plots of cowpea planted under intercropping, mono cropping and rotational systems may have been attributed to the improvement of soil structure and soil organic matter by cowpea. This agreed with similar findings by Reckling et al. (2014) who reported that inclusion of grain legumes in rotation either as a sole crop or as an intercrop provided $\mathrm{N}$-inputs into the system. The higher level of $\mathrm{N}-\mathrm{NO}_{3}$ in plots treated with $\mathrm{N}$ fertilizer agreed with similar findings by Sadej and Przekwas (2008) who reported that $\mathrm{N}$ fertilization significantly increased total soil $\mathrm{N}$ in the surface of $30 \mathrm{~cm}$.

\section{Soil Bray 1-P}

At Potchefstroom and Rustenburg, Bray 1-P was decreased in soil at the end of cropping as compared to $P$ obtained before planting of trial (Table 1). This implied the high uptake of phosphorus during growth of both maize and cowpea. The amount of $P$ (Bray-1) should be between the critical levels of $8-15 \mathrm{mg} \mathrm{kg}^{-1}$ (Miao et al., 2015). The differences in soil $P$ across the sites may have been attributed to different soil type of sites. This confirmed statements by Shahram and Ali (2015) that the processes behind $\mathrm{P}$ losses were complex and influenced by natural factors such as soil properties and weather condition. The coarse textured soil without macro pores, the direct risk of $P$ leaching losses after application of $P$ was generally low due to adsorption of $P$ (Wang et al., 2014). The high percentage of Bray 1-P in mono cropping maize was not expected in this study. This study shows that it was possible to obtain high soil Bray 1-P content under sole maize as compared to sole cowpea. This could be attributed to high uptake of soil available phosphorus during vegetative and reproductive stage of cowpea crop. Hassan et al. (2012) reported that legumes had the ability to solubilise $P$ from less pool in the soil. This corroborated with the findings of this study, where Bray 1-P was less in mono cropping and rotational cowpea plots. It was also reported by Hassan et al. (2012) that including legume in rotation increases phosphorus availability to the following crop due to their deep roots. The differences in soil phosphorus across the 
024 Int. Res. J. Agric. Sci. Soil Sci.

seasons may have been attributed to poor drainage system that led to flooding.

\section{Soil exchangeable $\mathrm{K}$}

The amount of exchangeable $\mathrm{K}$ decreased at the end of cropping in Potchefstroom and Rustenburg as compared to the amount of exchangeable $\mathrm{K}$ obtained before cropping (Table 1). This indicated the high uptake of exchangeable $\mathrm{K}$ during cropping seasons by both cowpea and maize. The decrease in exchangeable $\mathrm{K}$ during the end of cropping was at Potchefstroom and Rustenburg where clay percentage was high. The amount of exchangeable $\mathrm{K}$ was increased in the end of cropping at Taung, where percentage of sand was high. This indicated the benefits of maize-cowpea rotation, intercropping and nitrogen fertilisation, by improving the amount of exchangeable $\mathrm{K}$ in sandy soil. Fox and Valenzuela (1989) reported that the critical levels of potassium (K) should be $40 \mathrm{mg} \mathrm{kg}^{-1}$. The less content of exchangeable $\mathrm{K}$ in soil of Potchefstroom and Rustenburg at the end of cropping may have been attributed to high uptake of available $\mathrm{K}$ by crops. This confirmed the findings by Oldah (2011) who reported that when plant use $\mathrm{K}$ present in the soil solution, more $\mathrm{K}$ was released from the clay particles to the solution in response to decreased in concentration. The higher exchangeable $\mathrm{K}$ during 2012/13 planting season may have been attributed to the rate of rainfall, which had not led to severe leaching of $\mathrm{K}$ from surface soil. This confirmed statements by Shahbazi and Towfighi (2006) that exchangeable $\mathrm{K}$ decreased with increasing soil saturation. In terms of site and season, Tsukamoto et al. (2013)found that some soil properties improved at locations where higher amount of precipitation and lower temperature occurred.

\section{CONCLUSIONS}

The inclusion of legume in cropping system improves soil $\mathrm{N}-\mathrm{NO}_{3}$ and $\mathrm{N}-\mathrm{NH}_{4}$. The interaction effect of cropping system $x$ site $x$ season on Bray 1-P, N-NO ${ }_{3}$ and exchangeable $K$ had contributed towards the improvement of soil fertility status. Soil chemical properties are affected by different planting seasons due to different climatic factors. Location plays a major role on the availability of soil Bray $1-\mathrm{P}, \mathrm{N}-\mathrm{NO}_{3}$ and exchangeable $\mathrm{K}$.

\section{ACKNOWLEDGEMENTS}

The authors would like to thank the ARC-GCI and University of KwaZulu-Natal for allowing the study to take place. The study was funded by Agricultural Research
Council (ARC) and National Research Foundation (NRF). The financial assistance of the National Research Foundation (NRF) towards this research is hereby acknowledged. Opinions expressed and conclusions arrived at, are those of the author and are not necessarily to be attributed to the NRF.

\section{REFERENCES}

Adu-Gyamfi JJ, Myaka FA,Sakala WD, Odgaard R, Vesterager JM, Hogh-Jensen $H$ (2007). Biological nitrogen fixation and nitrogen and phosphorus budgets in farmer-managed intercrops of maize-pigeon pea in semi-arid Southern and Eastern Africa. Plant Soil 295: $127-$ 136.

Alam KM, Islam M, Salahin N, Hasanuzzaman M (2014). Effect of tillage practices on soil properties and crop productivity in wheatmungbean-rice cropping system under subtropical climatic condition. The Scientific World Journal. vol 2014. Article ID 437283. 15 pages. doi: $10.1155 / 2014 / 437283$.

Botha ADP, Snyman HG, Hahne HCH, Prinsloo AL, Steenkamp CJ, Duplessis DP (1968). Eienskappe van die gronde van die navorsings institute vir Tabak. Tegniese Mededeling 74. Rustenburg: Department van Landbou-Tegniese Dienste.

Bray RH, Kurts LT(1945). Determination of total organic and available forms of phosphorus in soil. Science 59: 39-45.

Dahmardeh M, Ghanbari A, Syahsar BA, Ramrodi M (2010). The role of intercropping maize (Zea mays L.) and cowpea (Vigna unguiculata L.) on yield and soil chemical properties. African J. Agric. Res. 5 (8): 631-636.

Fox RL, Valenzuela H (1989). Vegetables grown under tropical and sub-tropical conditions. P 293-337. In: IFA World Fertilizer use Manual. International fertilizer Industry Association.

Gomez KA, Gomez AA (1984). Statistical Procedures for Agricultural Research. John Wiley and Sons. New York.

Hassan MH, Marschner P,McNeill A, Tang C (2012). Growth, P uptake in grain legume and changes in rhizosphere soil $\mathrm{P}$ pools. Biology and Fertility of Soils 48: 151-159.

Jagadamma S, Lal R, Hoeft RG, Nafziger ED, Adee EA (2007). Nitrogen fertilization and cropping system impacts on soil properties and their relationship to crop yield in the central Corn Belt, USA. Soil and Tillage Research 98: 120-129.

Macvicar CN, De Villiers JM, Loxton RF, Verster E, Lambrechts JJN, Merryweather FR, Le Roux J, Van Rooyen TH, Harmse HJ (1977). Soil classification. A binomial system for South Africa. Science Bull. 390, ARC-Institute for Soil Climate and Water, Pretoria.

Miao YF, Wang ZH, Li SX (2015). Relation of nitrate $\mathrm{N}$ accumulation in dryland soil with wheat response to $\mathrm{N}$ fertilizer. Field Crops Research 170, 119-130.

Najmadeen HH, Mohammad AO, Mohamed-Amin HM (2010). Effects of soil texture on chemical compositions, microbial populations and carbon mineralization in soil. Egyptian J. Experimental Biology (Botany) 6 (1): 59-64.

Oldah D (2011). Potassium in Mississippi soil. Mississippi State University. Extension Service.

Omokanye AT, Kelleher FM, Mcinnes A (2011). Low-input cropping systems and nitrogen fertilizer effects on crop production: Soil nitrogen dynamics and efficiency of nitrogen use in maize crop. American Eurasian J. Agric. and Environ. Sci. 11 (2): 282-295.

Pule-Meulenberg F, Belane AK, Krasova-Wadet A, Dakora FD (2010). Symbiotic functioning and bradyrhizobial biodiversity of cowpea (Vigna unguiculata L. walp.) in Africa. BMC Microbiology.

Qi G, Wang Q, Zhou W, Ding H, Wang X, Qi L, Wang Y, Li S, Dai L (2011). Moisture effect on carbon and mineralization in topsoil of Changbai Mountain, Northern China. J. Forest Sci. 57: 340-348.

Reckling M, Preissel S, Zander P, Topp CFC, Watson CA, MurphyBokern D, Stoddard FL (2014). Effects of legume cropping on farming and food systems. Legume Futures Reports 1.6.

Sadej W, Przekwas K (2008). Fluctuations of nitrogen levels in soil 
profile under conditions of long-term fertilization experiment. Plant, Soil and Environment 54 (5): 197-203.

Sanginga N,Woomer PL (2009). Intergrated soil fertility management in Africa: Principles, Practices and development process. (eds.). Tropical Soil Biology and Fertility Institute of the International Centre for Tropical Agric. Nairobi. P.263.

Sarker MJU, Siddiky MA, Jahiruddin M, Mian MH, Islam MS (2011). Uptake of different nutrient elements by legume crops in wheatlegume T. Aman cropping pattern. Bangladesh J. Agric. Res. 36 (2): 247-253.

Seran TH, Brintha I (2010). Review on maize based intercropping. Journal of Agronomy 9 (3): 135-145.

Shahbazi K, Towfighi H (2006). Effects of different moisture regimes on soil exchangeable potassium. Iranian J. Agric. Sci. 38: 161-171.

Shahram G, Ali A (2015). Phosphorus losses in agricultural runoff from corn fields (case study, north of Khuzestan, Dezful, Iran). Adv. Biores 6 (3): 100-102.
Soil Survey Staff (1999). Keys to soil taxonomy ( $8^{\text {th }}$ edn.). Poca-hontas Press Inc., Blacksburg. Virginia.

Tittonell P, Shepherd KD, Vanlauwe B, Giller KE (2008). Unravelling the effect of soil and crop management on maize productivity in small holder agricultural systems of western Kenya. An application of classification and regression tree analysis. Agriculture, Ecosystems and Environment 123: 137-150.

Tsukamoto M, Inagaki T, Sasaki Y, Oda K (2013). Influence of relative density on microbial carbonate precipitation and mechanical properties of sand. Proceedings of the $18^{\text {th }}$ International Conference on Soil Mechanics and Geotechnical Engineering, Paris. P. 26132616.

Wang, YZ, Chen X, Lu CY, Zhao MQ, Du YF,Shi Y (2014). Effect of P application rate and frequency on $\mathrm{P}$ adsorption and water extractable $\mathrm{P}$ in a meadow brown soil over 12 year field micro-plot trials. Fresenius Environmental Bulletin. Volume 23 (7) 